\title{
Pengaruh Pelayanan Kesehatan terhadap Gizi Buruk Anak Usia 6 - 24 Bulan
}

\section{The Influence of Health Services Towards Nutrition Status of Children Aged Between 6 and 24 Months}

\author{
Erna Kusumawati, Setiyowati Rahardjo
}

Jurusan Kesehatan Masyarakat Fakultas Kedokteran dan Ilmu-ilmu Kesehatan Universitas Jenderal Soedirman Purwokerto

\begin{abstract}
Abstrak
Gizi kurang dan gizi buruk merupakan penyebab kematian sekitar $55 \%$ anak di bawah usia lima tahun di seluruh dunia. Kelompok usia 6 - 24 bulan merupakan masa kritis anak karena selain merupakan periode pertumbuhan kritis juga karena kegagalan tumbuh mulai terlihat. Tujuan penelitian ini adalah menilai faktor risiko gizi buruk anak usia $6-24$ bulan dalam upaya mengendalikan pencegahan dan pengendalian gizi buruk. Penelitian menggunakan rancangan studi kasus kontrol pendekatan retrospektif. Faktor risiko yang berpengaruh adalah pemanfaatan pelayanan kesehatan (odds ratio, $\mathrm{OR}=12,5)$, penyakit infeksi $(\mathrm{OR}=4,04)$, pola asuh makan (OR $=4,8)$; dan pendapatan keluarga $(O R=5,8)$. Peningkatan status gizi anak diupayakan dengan meningkatkan peran posyandu dan ibu dalam upaya pencegahan penyakit infeksi serta mensosialisasikan menu gizi seimbang agar anak dapat tumbuh dan kembang secara optimal.
\end{abstract}

Kata kunci: Faktor risiko, gizi buruk, anak 6 - 24 bulan

\begin{abstract}
Malnutrition is the cause of death of about $55 \%$ of children under the age of five worldwide. A critical period happen on children aged between 6 and 24 months because those ranges of age groups indicate extremely serious condition regarding their growth. The objective of this research was to identify risk factors for the occurrence of malnutrition on children between 6 and 24 months at the Health Center of Kembaran I, Banyumas Regency as an effort to develop a model for controlling them. This research used a case control design with a retrospective approach towards eighty-six children. Data was analyzed using univariate, bivariate and multivariate (logistic regression) methods The risk factors that influenced to the occurrence of malnutrition were the use of health services (odds ratio, $O R=12,5$ ); infectious diseases $(O R=4,04)$; eating pattern $(O R=4,8)$; and family income $(O R=$ $5,8)$. As a suggestion, to improve a nutrition status on children, it needs to increase roles of an integrated services post and roles of mothers as efforts to prevent infectious diseases and socialize balanced nutrition menu to
\end{abstract}

achieve a child's growth and development optimally.

Key words: Risk factors, malnutrition, children aged between 6 and 24 months

\section{Pendahuluan}

Gizi kurang dan gizi buruk merupakan penyebab kematian sekitar 55\% anak di bawah usia lima tahun (balita) di seluruh dunia. Di negara berkembang, hal tersebut disebabkan oleh kekurangan gizi yang berhubungan dengan diare, infeksi saluran pernapasan, campak, dan malaria. Kematian akibat gizi buruk tersebut secara tidak langsung menimpa keluarga miskin yang tidak terakses pelayanan kesehatan, kekurangan vitamin A dan zink selama dalam kandungan, serta kematian anak pada usia 2 tahun pertama. ${ }^{1}$ Masa bayi dan kanak-kanak adalah masa pertumbuhan dan perkembangan yang cepat dan sangat penting karena merupakan landasan yang menentukan kualitas generasi bangsa. Umur 6 - 24 bulan merupakan masa kritis anak karena pada periode tersebut tanda dan gejala gagal tumbuh umumnya mulai terlihat. ${ }^{2}$ Derajat gagal tumbuh yang paling berat sering kali terjadi pada usia 6 - 24 bulan. ${ }^{3}$ Penyebab gagal tumbuh tersebut adalah keadaan gizi ibu selama hamil, pola makan bayi yang salah, dan penyakit infeksi.

Gizi buruk dipengaruhi oleh banyak faktor yang saling terkait antara lain konsumsi makanan yang kurang dan penyakit infeksi. ${ }^{4}$ Secara tidak langsung juga dipengaruhi oleh pola asuh anak, ketersediaan pangan, da-

Alamat Korespondensi: Erna Kusumawati, Jurusan Kesehatan Masyarakat Gd. B Kampus Karangwangkal FKIK Universitas Jenderal Soedirman Purwokerto 53122, Hp.081328863042,e-mail: erna_watifadhila@yahoo.com 
Tabel 1. Tabulasi Silang Kejadian Gizi Buruk Berdasarkan Berbagai Faktor Risiko

\begin{tabular}{|c|c|c|c|c|c|}
\hline \multirow{2}{*}{ Variabel } & \multirow{2}{*}{ Kategori } & \multicolumn{2}{|c|}{ Kasus } & \multicolumn{2}{|c|}{ Kontrol } \\
\hline & & $\mathbf{n}$ & $\%$ & $\mathbf{n}$ & $\%$ \\
\hline \multirow[t]{2}{*}{ Pendidikan } & Rendah & 42 & 97,7 & 41 & 95,3 \\
\hline & Tinggi & 1 & 2,3 & 2 & 4,7 \\
\hline \multirow[t]{2}{*}{ Pekerjaan } & Tidak bekerja & 30 & 69,8 & 39 & 90,7 \\
\hline & Bekerja & 13 & 30,2 & 4 & 9,3 \\
\hline \multirow[t]{2}{*}{ Penghasilan } & $<$ UMK & 29 & 67,4 & 14 & 32,6 \\
\hline & $\geq \mathrm{UMK}$ & 14 & 32,6 & 29 & 67,4 \\
\hline \multirow[t]{2}{*}{ Jumlah keluarga } & Besar & 9 & 20,9 & 8 & 18,6 \\
\hline & Kecil & 34 & 79,1 & 35 & 71,4 \\
\hline \multirow[t]{2}{*}{ Pengetahuan } & Kurang & 25 & 58,1 & 14 & 32,6 \\
\hline & Baik & 18 & 41,9 & 29 & 68,4 \\
\hline \multirow[t]{2}{*}{ Pola asuh makanan } & Kurang & 26 & 60,5 & 14 & 32,6 \\
\hline & Baik & 17 & 39,5 & 29 & 68,4 \\
\hline \multirow[t]{2}{*}{ Pola asuh kesehatan } & Kurang & 22 & 51,2 & 14 & 32,6 \\
\hline & Baik & 21 & 48,8 & 29 & 68,4 \\
\hline \multirow[t]{2}{*}{ Pola makan } & Kurang & 26 & 60,5 & 26 & 60,5 \\
\hline & Baik & 17 & 39,5 & 17 & 39,5 \\
\hline \multirow[t]{2}{*}{ Penyakit infeksi } & Ya & 28 & 65,1 & 16 & 37,2 \\
\hline & Tidak & 15 & 35,9 & 27 & 63,8 \\
\hline \multirow[t]{2}{*}{ Akses pelayanan kesehatan } & Kurang & 34 & 79,1 & 17 & 39,5 \\
\hline & Baik & 9 & 21,9 & 26 & 61,5 \\
\hline \multirow[t]{2}{*}{ Sanitasi lingkungan } & Kurang & 21 & 48,8 & 14 & 32,6 \\
\hline & Baik & 22 & 52,2 & 29 & 68,4 \\
\hline \multirow[t]{2}{*}{ Paparan informasi } & Kurang & 39 & 90,7 & 32 & 74,4 \\
\hline & Baik & 4 & 9,3 & 11 & 26,6 \\
\hline
\end{tabular}

ya beli rendah yang dipengaruhi oleh penghasilan, pendidikan, pemeliharaan kesehatan, dan lingkungan. Selain itu, kondisi rumah tangga, jumlah anggota keluarga, serta sanitasi di dalam dan di luar rumah juga berpengaruh. Sementara faktor sosial ekonomi, budaya, dan politik merupakan faktor mendasar yang menjadi akar permasalahan. Secara perlahan, kekurangan gizi akan berdampak pada peningkatan angka kematian ibu, bayi dan balita, serta umur harapan hidup yang rendah. Dampak kekurangan gizi juga terlihat pada partisipasi sekolah, pendidikan, serta pertumbuhan ekonomi yang lambat. ${ }^{5}$

Di Kabupaten Banyumas, prevalensi gizi buruk dan gizi kurang pada balita dilaporkan sekitar $0,14 \%$ dan $1,95 \% .6$ Puskesmas I Kembaran mempunyai jumlah balita gizi kurang $6 \%$ dan gizi buruk $0,29 \%$ di atas prevalensi kabupaten. Frekuensi balita dengan status gizi kurang dan gizi buruk yang tinggi tersebut mendorong minat untuk mengetahui faktor risiko gizi buruk pada anak usia 6 - 24 bulan di Puskesmas I Kembaran. Tujuan penelitian ini adalah untuk mengkaji faktor risiko kejadian gizi buruk pada anak usia $6-24$ bulan di Puskesmas I Kembaran Kabupaten Banyumas dalam upaya mencegah dan mengendalikan penderita gizi buruk dan gizi kurang.

\section{Metode}

Penelitian ini menggunakan desain studi kasus kontrol yang merupakan desain studi observasional untuk mempelajari berbagai faktor risiko masalah kesehatan yang jarang ditemukan. Instrumen penelitian adalah kuesioner dengan jawaban tertutup dan terbuka tentang berbagai faktor risiko yang meliputi pendidikan ibu, pekerjaan ibu, tingkat pendapatan, pengetahuan gizi, dan kesehatan ibu. Juga dikumpulkan variabel jumlah anggota keluarga, pola asuh makanan, kesehatan, penyakit infeksi, akses pelayanan kesehatan, sanitasi lingkungan, keterpaparan informasi, serta gizi buruk. Populasi dalam penelitian adalah semua balita yang mempunyai status gizi buruk di Puskesmas I Kembaran. Sampel kasus adalah 43 balita gizi buruk periode bulan Juli - Oktober tahun 2010 dengan perbandingan kontrol $1: 1$. Metode analisis yang digunakan meliputi analisis univariat, bivariat, dan multivariat regresi logistik ganda.

\section{Hasil}

Variabel yang terdistribusi berbeda pada kelompok kasus dan kontrol meliputi ibu bekerja $(30,2 \%$ dan 9,3\%); penghasilan < upah minimum karyawan (UMK) (67,4\% dan $32,6 \%)$; pengetahuan gizi dan kesehatan kurang $(58,1 \%$ dan $32,6 \%)$; pola asuh makan yang kurang ( $60,5 \%$ dan $32,6 \%$ ); pola asuh kesehatan kurang $(51,2 \%$ dan $32,6 \%)$; penyakit infeksi $(65,1 \%$ dan $37,2 \%)$; akses pelayanan kesehatan kurang $(79,1 \%$ dan $39,5 \%)$; sanitasi lingkungan kurang (48,8\% dan 32,6\%); dan paparan informasi kurang $(90,7 \%$ dan $74,4 \%)$ (Lihat Tabel 1). 
Tabel 2. Analisis Bivariat Faktor Risiko Gizi Buruk

\begin{tabular}{|c|c|c|}
\hline Variabel & Kategori & Nilai $\mathrm{p}$ \\
\hline Pendidikan & $\begin{array}{l}\text { Rendah } \\
\text { Tinggi }\end{array}$ & 1,000 \\
\hline Pekerjaan & $\begin{array}{l}\text { Tidak bekerja } \\
\text { Bekerja }\end{array}$ & 0,03 \\
\hline Pendapatan & $\begin{array}{l}<\mathrm{UMK} \\
\geq \mathrm{UMK}\end{array}$ & 0,003 \\
\hline Jumlah keluarga & $\begin{array}{l}\text { Besar } \\
\text { Kecil }\end{array}$ & 1,00 \\
\hline Pengetahuan & $\begin{array}{l}\text { Kurang } \\
\text { Baik }\end{array}$ & 0,03 \\
\hline Pola asuh makanan & $\begin{array}{l}\text { Kurang } \\
\text { Baik }\end{array}$ & 0,017 \\
\hline Pola asuh kesehatan & $\begin{array}{l}\text { Kurang } \\
\text { Baik }\end{array}$ & 0,13 \\
\hline Pola makan & $\begin{array}{l}\text { Kurang } \\
\text { Baik }\end{array}$ & 1,00 \\
\hline Penyakit infeksi & $\begin{array}{l}\text { Ya } \\
\text { Tidak }\end{array}$ & 0,018 \\
\hline Akses pelayanan kesehatan & $\begin{array}{l}\text { Kurang } \\
\text { Baik }\end{array}$ & 0,00 \\
\hline Sanitasi lingkungan & $\begin{array}{l}\text { Kurang } \\
\text { Baik }\end{array}$ & 0,19 \\
\hline Paparan informasi & $\begin{array}{l}\text { Kurang } \\
\text { Baik }\end{array}$ & 0,08 \\
\hline
\end{tabular}

Tabel 3. Hasil Analisis Multivariat dengan Uji Regresi Logistik Ganda

\begin{tabular}{lll}
\hline Variabel & Nilai $\mathbf{p}$ & OR \\
\hline Penyakit infeksi & 0,019 & 4,05 \\
Pola asuh makan & 0,010 & 4,83 \\
Pemanfaatan pelayanan kesehatan & 0,000 & 12,49 \\
Pendapatan & 0,003 & 5,80 \\
\hline
\end{tabular}

\section{Analisis Bivariat}

Pemilihan kandidat variabel multivariat dilakukan dengan analisis bivariat dengan kriteria nilai $\mathrm{p} \leq 0,25$. Hanya variabel pendidikan, jumlah keluarga, dan pola makan yang tidak memenuhi kriteria kandidat model tersebut (nilai $\mathrm{p}=1,00$ ), selebihnya memenuhi kriteria (Lihat Tabel 2).

\section{Analisis Multivariat}

Hasil analisis regresi logistik ganda ditemukan variabel yang berpengaruh secara bermakna secara multivariat terhadap gizi buruk meliputi infeksi, pola asuh makanan, pendapatan, dan pemanfaatan pelayanan kesehatan. Faktor yang paling berpengaruh adalah pemanfaatan pelayanan kesehatan dengan nilai $\mathrm{p}=0,000$ dan nilai odds ratio (OR) sebesar 12,49 (Lihat Tabel 3).

\section{Pembahasan}

Sebagian besar ibu berpendidikan dasar $\leq 9$ tahun sesuai dengan hasil Riset Kesehatan Dasar (Riskesdas)
2007,7 memiliki anak dengan status gizi buruk dan gizi kurang semakin besar. Hal ini sesuai dengan hasil penelitian Fatmah, ${ }^{8}$ bahwa hampir seluruh ibu balita memiliki tingkat pengetahuan rendah tentang perilaku sadar gizi yang dapat disebabkan mayoritas informan menamatkan pendidikan akhirnya di tingkat SMP. Ibu yang bekerja di luar rumah akan dapat menurunkan frekuensi dan durasi menyusui serta waktu untuk merawat anaknya yang mengalami sakit. ${ }^{9}$ Responden dangan tingkat pendapatan yang cukup tetapi memiliki balita berstatus gizi buruk, kemungkinan disebabkan oleh faktor balita yang malas makan, pengetahuan ibu tentang gizi kurang, pemberian makanan pada balita yang tidak tentu, serta penyakit infeksi. Anak berstatus gizi buruk pada umumnya ditemui dari keluarga yang kurang mampu secara ekonomi. Berbagai kondisi yang dapat menyebabkan status kesehatan yang buruk menyebabkan penyakit infeksi seperti sanitasi lingkungan perumahan yang buruk. Anak penderita gizi kurang lebih rentan sehingga lebih mudah infeksi terjadi, sebaliknya penderita penyakit infeksi lebih rentan kekurangan gizi akibat peningkatan metabolisme tubuh sehingga kebutuhan asupan makanan meningkat. 10

Setiap orang hanya akan cukup gizi jika makanan yang dimakan mampu menyediakan zat gizi yang diperlukan untuk pertumbuhan tubuh yang optimal, pemeliharaan, dan energi. Banyak peneliti menemukan masalah gizi buruk disebabkan oleh ketidaktahuan terhadap gizi sehingga banyak jenis bahan makanan yang tidak dimanfaatkan untuk konsumsi anak. Pola asuh makan anak akan selalu terkait dengan pemberian makan yang akhirnya akan memberikan sumbangan terhadap status gizi anak. Ibu memiliki peranan penting dalam menatalaksanakan makanan bagi anak serta menjamin terpenuhinya kebutuhan anak akan makanan bergizi. ${ }^{11}$ Aspek sanitasi lingkungan juga sangat menentukan kondisi kesehatan bayi. Kurangnya perhatian keluarga, terutama ibu, dalam hal sanitasi lingkungan dapat meningkatkan kerentanan bayi terhadap penyakit infeksi dan mengurangi kesempatan anak untuk mengeksplorasi lingkungan. ${ }^{12}$

Berdasarkan hasil wawancara menunjukkan bahwa ibu yang mempunyai anak dengan gizi buruk kurang aktif datang ke posyandu karena merasa kurang percaya diri sehubungan dengan kondisi anaknya. Sebagian ibu merasa tidak perlu datang ke pelayanan kesehatan jika anaknya sakit (misalnya batuk pilek) karena merasa bisa diobati dengan obat pasaran dan akan sembuh sendiri. Kemampuan suatu rumah tangga untuk mengakses pelayanan kesehatan berkaitan dengan ketersediaan sarana pelayanan kesehatan serta kemampuan ekonomi untuk membayar biaya pelayanan. ${ }^{13}$ Ketidakterjangkauan pelayanan kesehatan dimungkinkan karena keluarga tidak mampu membayar serta kurang pendidikan dan pengetahuan sehingga menjadi kendala 
keluarga dalam memanfaatkan pelayanan kesehatan yang tersedia. Hal ini dapat berdampak pada status gizi masyarakat. ${ }^{14,15}$

Anak gizi buruk akan mengalami penurunan daya tahan sehingga rentan penyakit infeksi. Infeksi mempunyai kontribusi terhadap kekurangan energi, protein, dan zat gizi lain karena menurunnya nafsu makan sehingga tingkat kecukupan gizi menjadi berkurang. Kebutuhan energi pada saat infeksi dapat mencapai 2 kali kebutuhan normal karena meningkatnya metabolisme basal. Infeksi juga berpengaruh terhadap absorbsi dan katabolisme serta mempengaruhi praktik pemberian makanan selama dan sesudah sakit. ${ }^{9}$

Pola makan yang kurang bukan satu-satunya faktor yang menjadikan balita terhindar dari kejadian gizi buruk, tetapi ada beberapa faktor lain seperti salah satunya penyakit infeksi. Adanya penyakit infeksi seperti infeksi saluran pernafasan akut (ISPA) maupun diare pada balita menyebabkan makanan yang dikonsumsi balita akan terhambat penyerapannya dan energi yang didapatkan dari makanan akan habis atau berkurang.

\section{Pengendalian Faktor Risiko}

Posyandu merupakan salah satu organisasi yang sampai saat ini masih beroperasi hampir di seluruh desa/kelurahan di Indonesia. Penelitian yang dilakukan oleh Aminuddin, ${ }^{16}$ menunjukkan bahwa posyandu mampu mendorong pemantauan pertumbuhan anak. Sebagai wadah peran serta masyarakat, posyandu dilaksanakan oleh dan untuk masyarakat dalah hal menyelenggarakan sistem pelayanan pemenuhan kebutuhan dasar, dan peningkatan kualitas manusia. Salah satu upaya yang dapat dilakukan melalui pengembangan posyandu yang sudah ada dengan mengedepankan pemberdayaan masyarakat dalam menangani masalah gizi dan kesehatan masyarakat. Untuk mencapai hasil yang optimal, pengetahuan kader selalu harus diperbarui dengan melakukan penyegaran agar tercipta rasa percaya diri dalam memberikan pelayanan. Ibu merupakan pembina pertama dan utama terhadap anak di dalam keluarga. Seorang ibu mempunyai peran dan andil yang sangat besar dalam pembinaan anak. Mempersiapkan anak menjadi manusia yang berguna harus dimulai sejak usia dini melalui peran ibu dan pola asuh yang baik. ${ }^{17}$

Seorang ibu mempunyai peranan yang besar dalam perkembangan status gizi balita. ${ }^{18}$ Peranan determinan pola asuh anak terhadap pertumbuhan anak cukup besar. Pola asuh yang baik dapat meningkatkan tingkat kecukupan gizi dan kesehatan anak. Pola asuh makanan dan kesehatan yang kurang akan menyebabkan konsumsi makanan kurang bervariasi. Optimalisasi peran ibu akan memberikan pengetahuan dan keterampilan mengenai pola asuh makanan dan kesehatan yang baik, menu gizi seimbang, dan pencegahan penyakit infeksi. ${ }^{19}$

\section{Kesimpulan}

Terdapat pengaruh bermakna antara pemanfaatan pelayanan, penyakit infeksi, pola asuh makan, pendapatan keluarga, pengetahuan, dan pekerjaan ibu terhadap status gizi buruk pada anak $6-24$ bulan. Tidak ada pengaruh antara pendidikan ibu, jumlah anggota keluarga, pola asuh kesehatan, pola makan, sanitasi lingkungan, dan keterpaparan informasi terhadap status gizi buruk anak $6-24$ bulan.

\section{Saran}

Peran posyandu dan peran ibu dalam upaya pencegahan penyakit infeksi dan mensosialisasikan menu gizi seimbang agar anak dapat tumbuh dan kembang secara optimal perlu ditingkatkan. Penelitian lebih lanjut tentang tindak lanjut faktor penyakit penyerta lain serta peran posyandu dan pelayanan kesehatan terhadap upaya peningkatan status gizi anak balita perlu dilaksanakan.

\section{Daftar Pustaka}

1. Malik A. Gizi buruk tewaskan 3,5 juta balita per tahun. 2008 [diakses tanggal 20 Juni 2010]. Diunduh dari: http://www.lifestyle.okezone.com.

2. Anwar A. Review peningkatan penggunaan ASI dan MP ASI. Bogor; 2000.

3. Latief D, Falah TS, Sumawang. Program ASI eksklusif dan makanan pendamping Air Susu Ibu (MP ASI). Proceedings diskusi pakar bidang gizi tentang ASI, MP ASI, Antropometri dan BBLR. Cipanas; 2000.

4. Schroeder DG. Malnutrition. In: Samba RD, Bluem MWL, editors. Nutrition and health in development countries. Tatawa: New Jersey Humania Press; 2001.

5. Badan Perencanaan Pembangunan Nasional. Rencana aksi nasional pangan dan gizi 2006 - 2010. Jakarta: Badan Perencanaan Pembangunan Nasional; 2007.

6. Dinas Kesehatan Kabupaten Banyumas. Profil kesehatan Kabupaten Banyumas 2008. Purwokerto: Dinas Kesehatan Kabupaten Banyumas; 2009.

7. Kementerian Kesehatan Republik Indonesia. Riset kesehatan dasar (riskesdas) 2007. Jakarta: Kementerian Kesehatan Republik Indonesia; 2008.

8. Fatmah. Pengetahuan dan praktek keluarga sadar gizi ibu balita. Kesmas, Jurnal Kesehatan Masyarakat Nasional. 2010; 4 (4): 162-71.

9. Thaha AR. Pengaruh musim terhadap pertumbuhan anak keluarga nelayan [disertasi]. Jakarta: Universitas Indonesia; 1995.

10. Achadi E, Arifah S, Muslimatun S, Anggondowati T, Setiarini A. Efektivitas program fortifikasi minyak goreng dengan vitamin A terhadap status gizi anak sekolah di Kota Makasar. Kesmas, Jurnal Kesehatan Masyarakat Nasional. 2010; 4 (6): 255-61.

11. Kusin JA, Kardjati S. Maternal and child nutrition in Madura, Indonesia. Amsterdam: Royal Tropical Institute the Netherlands; 1994.

12. Dewey KG, Bohem RJ, Brown KH, Rivera LL. Age to introduction of complementary foods and grown of term, infants birth weight, breastfeeding infant: a randomized interventon in Honduras. Am J. Cin. Nutr. 1999; 69: 679-86.

13. Sartika RAD. Analisis pemanfaatan program pelayanan kesehatan status 
gizi balita. Kesmas, Jurnal Kesehatan Masyarakat Nasional. 2010; 5 (2): 76-83.

14. Soekirman. Ilmu gizi dan aplikasinya. Jakarta: Kementerian Pendidikan Nasional; 2001.

15. Lembaga Ilmu Pengetahuan Indonesia. Ketahanan pangan dan gizi di era otonomi daerah dan globalisasi. Prosiding Widyakarya Nasional Pangan Dan Gizi VIII. Jakarta; 2004.

16. Aminuddin, Zulkifli A, Djafar N. Peningkatan peran posyandu partisipatif melalui pendampingan dan pelatihan upaya pemantauan pertumbuhan dan masalah gizi balita di Bone, Sulawesi Selatan. Kesmas, Jurnal Kesehatan Masyarakat Nasional. 2011; 5 (5): 201-5.
17. Darmadji S. Perkembangan anak balita: program bina keluarga dan balita buku IV. Jakarta: Kantor Menteri Negara Urusan Peranan Wanita; 1993.

18. Engle P. Care and child nutrition. Procedings of the International Nutrition Conference (ICN). New York: United Nations Children's Fund; 1992.

19. Rahardjo S, Kusumawati E. Perbedaan pola asuh makanan, pola asuh kesehatan, dan pengetahuan gizi pada balita dengan status gizi gemuk, normal, dan kurus (studi di Puskesmas II Sumbang Kabupaten Banyumas). Purwokerto: Fakultas Kedokteran dan Ilmu-ilmu Kesehatan Universitas Jenderal Soedirman; 2009. 